\title{
Billeder, tekst og tale
}

- idrætshistorisk formidling med udgangspunkt i udstillingen: »Sport \& Krig i Medierne. Fra Gunnar Nu til Muhammedkrise «, Brandts Danmarks Mediemuseum, Odense 23. juni-23. september 2007 og Hans Bonde: Niels Bukh. En politisk-ideologisk biografi« CD-ROM + DVD. Museum Tusculanums Forlag 2007.

\section{Af Jørn Hansen}

Blandt historikere har det været en fremherskende opfattelse, at historien bliver til ved hjælp af teksterne. Det vil sige det materiale man bygger historien på primært har været skriftligt materiale i form af levninger og beretninger, som man så kildekritisk har skullet forholde sig til. Skulle man ty til ikke-skriftlige kilder var det som regel fordi, de skriftlige overleveringer manglede, og man derfor var tvunget til at søge hjælp hos f.eks. arkæologer som tilfældet har været hos mange oldtidshistorikere. Selv om en række historikere allerede i 1950'erne plæderede for, at historien bygger på alt det, som historikerens opfindsomhed tillader denne at benytte, eller som Lucien Febvre formulerede det i Combat pour l'historie i 1953 »alt det, som tilhører mennesket, kendetegner menneskets tilstedeværelse, dets aktivitet, smag, væsen og optræden «, blev tekster opfattet som de vigtigste kilder.

Undertegnede havde således selv problemer med under historiestudiet i første halvdel af 1970'erne at få accepteret et billede som ikke skriftlig kilde ved eksamensopgi- velserne i det 20. århundredes historie. Argumentet var netop, at en ikke-skriftlig kilde var mere passende $i$ et emne inden for oldtidshistorien. I det 20. århundrede var der jo så rigeligt med skriftligt materiale. Det er selvfølgelig korrekt, at det 20. århundrede er rig på skriftlige efterladenskaber, men samtidig er det 20. århundrede også det århundrede, hvor nye medier som fotografiet, filmen, radioen og fjernsynet for alvor producerede nye kildetyper. Kildetyper, der især kan være med til at kaste et mere udførligt lys over idræt som mennesket i bevægelse og store idrætsbegivenheder som OL og fodboldlandskampe. I sit arbejde med såvel Niels Bukh som sport og politik har Hans Bonde været den idrætshistoriker, der mest konsekvent har gjort brug af billedmedier til dels at fuldstændiggøre arbejdet med de skriftlige kilder dels at analysere idræt som bevægelsesform.

Udstillingen på Danmarks Mediemuseum »Sport \& Krig i Medierne. Fra Gunnar $\mathrm{Nu}$ til Muhammedkrise « blev tilrettelagt i samarbejde med Hans Bonde på baggrund 
af Bondes Fodbold med Fjenden (2006) og behandlede primært danske avisers og Idrcetsbladets syn på dansk idræts samarbejde med Tyskland under nazismen 193345, hvor der især blev fokuseret på en række specialforbunds ofte meget ivrige samarbejde med Hitler-Tyskland. Derudover var der løbende en række filmklip fra Leni Riefenstahls »Olympiafilm« om OL i Berlin i 1936, en række klip fra uge-revyer, der normalt gik som forfilm til datidens biograffilm, enkelte radioreportager samt endelig nogle mere aktuelle TV-optagelser, dels fra George Bush' åbning af vinterlegene i Salt Lake City, dels hvor Kai Holm diskuterer dansk idrætspolitik i forhold til ytringsfrihed og Muhammedkrise. Udstillingen bestod af to rum og et mindre lokale til fremvisning af film, og var som omtalt især bygget op om tiden 1933-45.

I en anmeldelse af udstilling i Fyens Stiftstidende skrev kulturjournalisten, Marianne Koch, at hun fandt udstillingen næsten lige så ensidig i sin fordømmelse, som man i sin tid klandrede nazisterne for at være. Efter min opfattelse er der dog ikke belæg for dette udsagn. Udstillingens tekster og billeder dokumenterer klart, hvorledes flere aktører inden for den danske idrætsverden med stor glæde arbejdede sammen med nazisterne. Til gengæld er det min opfattelse, at udstillingens undertitel »Fra Gunnar Nu til Muhammedkrise« var en smule misvisende, eftersom det egentlig var et meget beskedent materiale, der omhandlede idræt og politik efter 1945. Jeg vil formode, at dette må skyldes pladsmangel, da der jo sådan set er rigeligt materiale at tage af. Især kunne man i den sammenhæng have gjort endnu bedre brug af det righoldige materiale, der må forefindes i Tv-mediets arkiv. Som en måde at formidle idrætshistorien til et bredere publikum på var udstillingen dog rimelig vellykket.

Rigtig vellykket er udgivelsen Hans Bondes Niels Bukh. En politisk-ideologisk biografi, 2007 som er et digitalt genoptryk af Hans Bondes disputats med samme titel fra 2001. Det drejer sig om en cd-rom med 910 sider digitaliseret tekst, der er fuldt søgbar med interaktive registre, integrerede billeder og filmklip med Hans Bondes kommentarer til filmklippene samt en DVD med 131 filmklip med dansk, engelsk eller japansk tale. Det er den samme DVD, der er vedlagt Hans Bondes »Gymnastics and Politics. Niels Bukh and Male Aesthetics« 2006, som er en bearbejdet kortere udgave af disputatsen for et engelskkyndigt publikum.

Især cd-rom'en, hvor tekst og billede er integreret er en god udnyttelse af de muligheder, som det digitale medier giver. Det er nemt at søge i teksten, og sammen med teksten kan man i den rette kontekst se billederne samt både se og lytte til de relevante filmklip, således at tekst og film flere steder går op i en højere enhed.

Den vedlagte DVD med titlen »Niels Bukh. A visual documentation on Gymnastics and Politics 1912-52« bringer i kronologisk orden billeder og filmklip fra Niels Bukhs liv og virke, hvor jeg ved gennemsynet blot har oplevet et enkelt misforhold mellem billede og tale, nemlig det sidste klip, hvor man på et billede ser Niels Bukh undervise karlene samtidig med, at teksten fortæller os, at den indlagte tale er Niels Bukh, der instruerer kvindegymnastik. Generelt handler det imidlertid om en fin illustreret kronologisk dokumentation, der dog som Hans Bonde selv gør opmærksom på $\mathrm{i}$ "Gymnastics and Poltics" i sin ofte minutiøse form savner det dramatiske islæt, der kendetegnede Niels Bukhs liv. Vælger man i stedet den tematiske tilgang til billede og 
filmklippene, hvor indgangen er temaer som »Gymnastikken«, »Italiensk fascisme«, »Verdensrejsen 1931《, »Nazismen« $\mathrm{m}$. v., kommer mediet bedre til sin ret. Det er for især idrætshistorien et oplagt scoop, at man får illustreret selve gymnastikkens æstetik, får et indblik i den overdimensionerede iscenesættelse af den Nordiske Olympiade i 1935, da idrættens sprog jo netop som regel er nonverbal.

DVD'en indeholder et fantastisk rigt og spændende billed- og filmmateriale, men den selvstændige status, som den umiddelbart får enten som supplement til den en- gelsksprogede publikation eller cd-rom'en gør, at den rent formidlingsmæssigt kommer til i al fald i mine øjne og ører til at fremstå som en lettere docerende skolefilmsproduktion. Det er selvfølgelig en ren subjektiv fornemmelse, hvor det nok især er de talte ord, der forstyrrer, fordi de firkantet fortæller mig, hvad jeg ser eller skal se. Selv om det for filmklippenes vedkommende er de samme ord, der går igen, finder jeg brugen af det digitale medie mere interessant og formidlingsmæssigt mest vellykket på den interaktive cd-rom. 
